\title{
Frequency and clinical significance of erythrocyte genetic abnormalities in Omanis
}

\author{
J M White, B S Christie, D Nam, S Daar, D R Higgs
}

\begin{abstract}
The frequencies of four malaria associated erythrocyte genetic abnormalities have been established in 1000 Omani subjects. They are: homozygous $\alpha^{+}$ thalassaemia $(-\alpha /-\alpha) 0.45$; high $\mathrm{Hb} \mathrm{A}_{2} \beta$ thalassaemia trait 0.015 ; sickle trait (Hb A/S) 0.061; and glucose 6 phosphate dehydrogenase deficiency $\left(\mathrm{Gd}^{-}\right)$: males $0 \cdot 27$, females 0.11 .

From our data the $\alpha^{+}(-\alpha /)$ thal gene (confirmed by Southern blotting) is pandemic in this population. Moreover, in spite of the very high frequency of $\mathrm{Gd}^{-}$, oxidative haemolytic syndromes are very uncommon. Also preliminary data indicate that among the Omani population with sickle cell disease, homozygosity of the $\alpha^{+}$gene markedly modifies the clinical picture.

( $\mathcal{F}$ Med Genet 1993;30:396-400)
\end{abstract}

Oman, situated in the south-east of the Arabian Peninsula, is a country of some 1.5 million people. The ethnic origin of the population is mainly Arab, but over the centuries considerable mixing has taken place with the East African and the Indian subcontinent. Interracial movement has come mostly via sea trade routes since Oman is geographically isolated from the rest of the Peninsula by a high mountain range along the western border. This separates it from the empty south-eastern desert quarter of Saudi Arabia.

A previous comparative study of the frequency of malaria associated erythrocyte genetic disorders in the Peninsular Arabs residing in the United Arab Emirates, namely UAE nationals, Saudis, Yemenis, and Omanis, indicated that in the Omanis the frequencies of two gene deletional type $\alpha$ thalassaemia and glucose 6 phosphate dehydrogenase deficiency, 0.389 and 0.328 respectively, were far greater than in the other three Arab populations. Moreover they appeared to be among the highest in any country so far reported. ${ }^{1}$ However, the number of subjects examined was too small to give accurate figures and, also, being an expatriate population the exact ethnic origin was uncertain.

We can now report data on the frequencies of $\alpha$ and $\beta$ thalassaemia, sickle haemoglobin (Hb S), and glucose 6 phosphate dehydrogenase deficiency $\left(\mathrm{Gd}^{-}\right)$in nearly 1000 Omanis, a third of whom were healthy subjects.

\section{Subjects}

Nine hundred and fifty-two Omani subjects, 435 males and 517 females, identified by tribal names, were studied. These comprised hospital patients $(73 \%)$ and university students $(27 \%)$. Of the hospital patients $83 \%$ were adults and the remainder children. To determine the frequencies of $\mathrm{HbS}, \mathrm{Gd}^{-}$, and $\beta$ thalassaemia the whole population was studied. However, with regard to $\alpha$ thalassaemia only the male student population was studied in detail and the data extrapolated to predict the frequency in the population as a whole.

One hundred and forty-two 'non-Arab' subjects, 82 males and 60 females, who were healthy blood donors, were used as a control population for comparing the haematological parameters. They came from North America, Great Britain, Northern Europe, India, and the Philippines.

\section{Methods}

The routine blood counts were measured on a Coulter S Plus VI cell analyser. Haemoglobin $\mathrm{A}_{2}$ was measured using Helena Beta-thal and Sickle-thal ion exchange chromatography columns. The normal range for the Omani phenotype $\mathrm{Hb} \mathrm{A} / \mathrm{Hb} \mathrm{A}$ for this laboratory was 1.8 to $3.5 \%$. Values greater than $4.5 \%$ were accepted as being diagnostic of high $\mathrm{Hb} \mathrm{A}_{2} \beta$ thalassaemia trait.

Blood was screened for haemoglobin S using Ortho Sickledex kits. Haemoglobin electrophoresis was performed on all positive samples on agar gel at $\mathrm{pH} 8.6$ and $\mathrm{pH} 6.0$ using the Beckman Paragon system.

Cord bloods were examined for the presence of $\mathrm{Hb} \mathrm{A}, \mathrm{Hb} \mathrm{S}$, and $\mathrm{Hb}$ Bart's by electrophoresis on agar gel at pH 8.6 and pH 6.0. The Hb Bart's was quantitated by scanning densitometry.

Haemoglobin $F$ levels were measured by high performance liquid chromatography (HPLC) using the Biorad 'Diamat' instrument. The normal range for Omanis was $<1 \%$.

Glucose 6 phosphate dehydrogenase (G6PD) activity was estimated using the Boehringer screening and quantitative kits. On deficient samples the activity was quantitated. Values less than $10 \mathrm{mU} / 10^{\circ} \mathrm{RBCs}$ were accepted as being deficient. The quoted normal range for this method was $131 \pm 13 \mathrm{mU} / 10^{9} \mathrm{RBCs}$.

The iron status of the patients was determined by measuring the serum ferritin levels using the Abbott IMX microparticle enzyme immunoassay method. A value of less than $15 \mathrm{ng} / \mathrm{ml}$ was indicative of iron deficiency.

Haemoglobin gene analysis was carried out as follows: $\alpha$ globin gene analysis on a subset of eight adult Omani subjects with haematological and biochemical parameters indicative of $\alpha$ thalassaemia was carried out by blot hybridisation using standard methods. ${ }^{2-4}$ The probes 


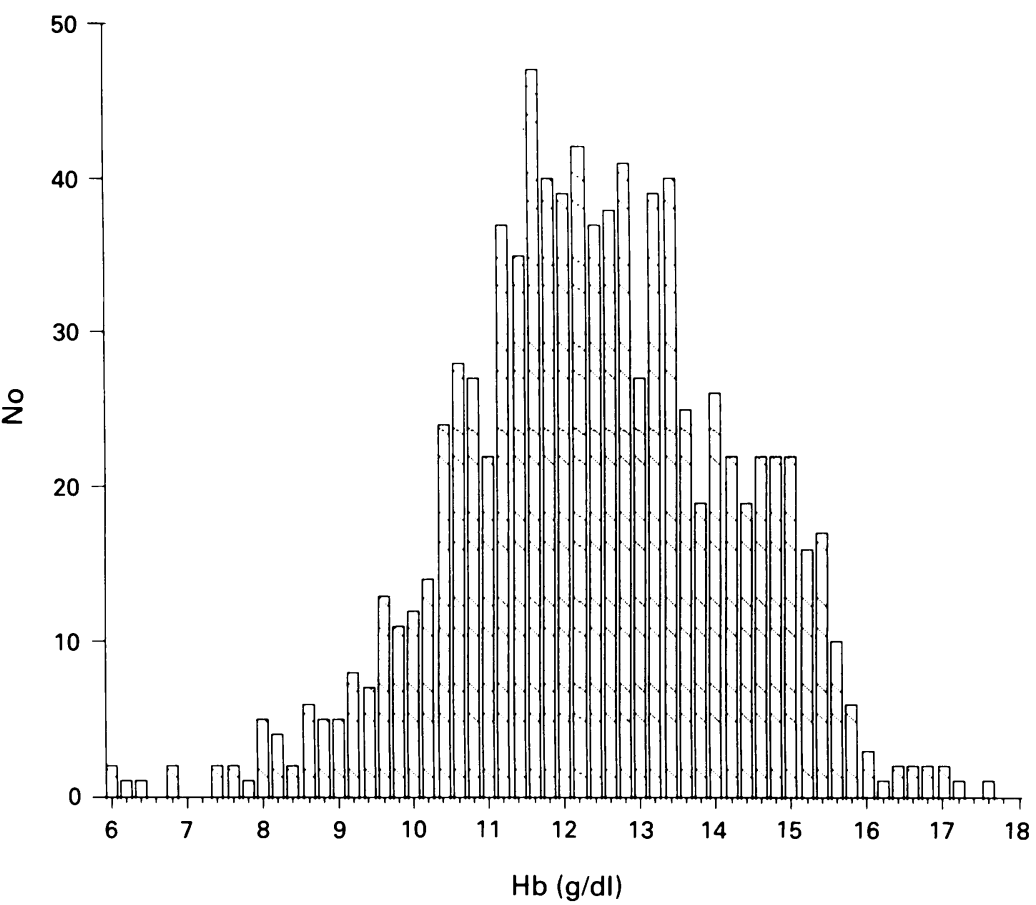

Figure 1 The distribution of Hb levels of the 952 Omani population studied. The geometric mean of $12.9 \mathrm{~g} / \mathrm{dl}(S D 2.95)$ is significantly different from our non-Arab value of $14.2 \mathrm{~g} / \mathrm{dl}(S D 2.60)(p=<0.001)$.

Table 1 Comparison between the red cell indices of Omani and the non-Arab population.

\begin{tabular}{|c|c|c|c|c|c|c|}
\hline \multicolumn{3}{|c|}{ Omani $(n=305)$} & \multicolumn{3}{|c|}{ Non-Arab $(n=145)$} & \multirow[b]{2}{*}{$\mathrm{p}$} \\
\hline Geom & ic means & $(2 \mathrm{SD})$ & Geom & ic means & $(2 \mathrm{SD})$ & \\
\hline $\begin{array}{l}\mathrm{Hb} \\
\mathrm{RBC} \\
\mathrm{MCH} \\
\mathrm{MCV}\end{array}$ & $\begin{array}{l}12.9 \mathrm{~g} / \mathrm{dl} \\
5.20 \times 10^{12} / 1 \\
24.8 \mathrm{pg} \\
75.5 \mathrm{fl}\end{array}$ & $\begin{array}{r}(2.95) \\
(1.52) \\
(6.54) \\
(15.06)\end{array}$ & $\begin{array}{l}\mathrm{Hb} \\
\mathrm{RBC} \\
\mathrm{MCH} \\
\mathrm{MCV}\end{array}$ & $\begin{array}{l}14.2 \mathrm{~g} / \mathrm{dl} \\
4.70 \times 10^{12} / 1 \\
30 \cdot 4 \mathrm{pg} \\
90 \cdot 0 \mathrm{fl}\end{array}$ & $\begin{array}{l}(2 \cdot 60) \\
(1 \cdot 2) \\
(3 \cdot 24) \\
(8 \cdot 42)\end{array}$ & $\begin{array}{l}<0.001 \\
<0.001 \\
<0.001 \\
<0.001\end{array}$ \\
\hline
\end{tabular}

The data on the Omani given are from the male and female student population to give a more meaningful comparison.

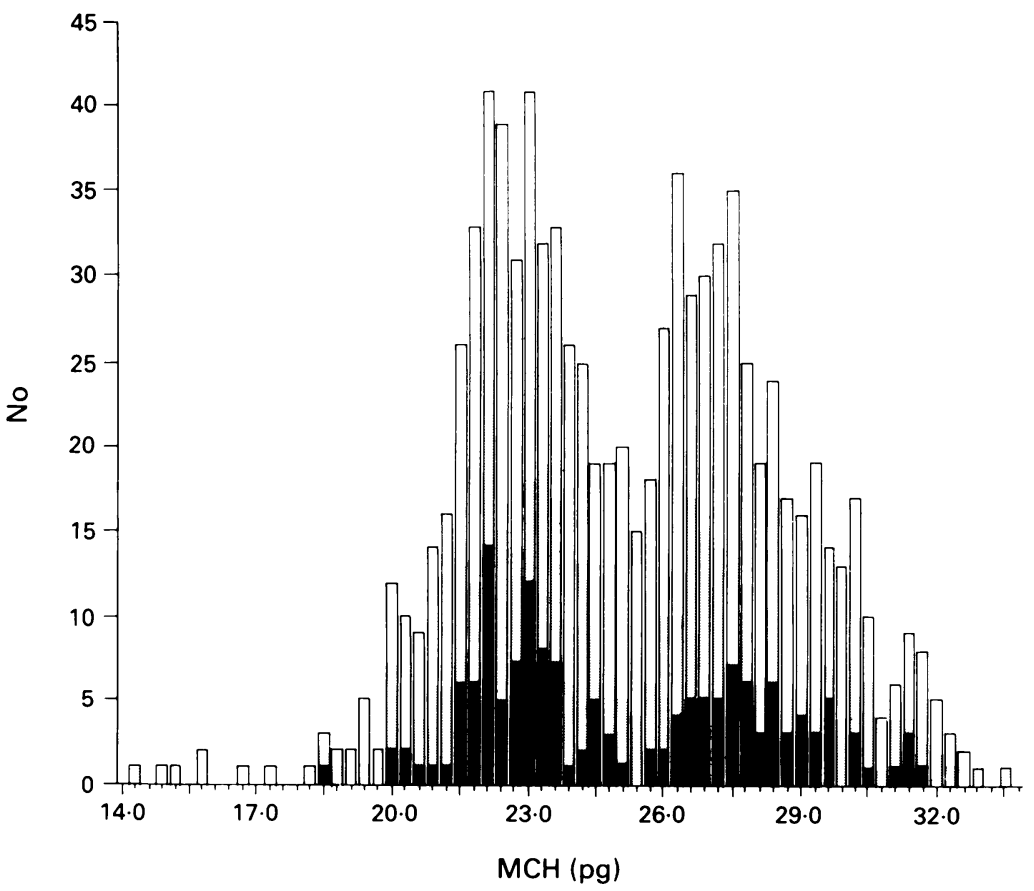

Figure 2 The distribution of the MCH among the Omani population studied. Total population (black); male hospital patients (grey); Omani male students (white). Two populations are seen and are constant throughout the population, group $A$ (MCH 14 to $25 \mathrm{pg}$ ) and group $B$ (MCH 25 to $32 \mathrm{pg}$ ). There is a slight overlap but the geometric means, 22.8 and $27.3 \mathrm{pg}$ respectively, are significantly different $(p<0.001)$. used in this study were $\alpha^{1}$ globin/HBAI ${ }^{5}$ and $\Psi \zeta 1$ globin/HBZP. ${ }^{6}$ In addition the $\beta$ globin genes of 29 patients with suspected homozygous $\beta$ thalassaemia were analysed using the amplified refractory mutation system. ${ }^{7}$

\section{Results}

The distribution of the haemoglobin values of the 952 subjects is shown in fig 1 . The curve was Gaussian but the geometric mean (GM) of 12.9 (SD 2.95) g/dl was significantly lower than that of our non-Arab population, 14.2 (SD 2.6) $\mathrm{g} / \mathrm{dl}(\mathrm{p}=0.001)$ (table 1$)$. The main factor responsible for this 'anaemia' was the low $\mathrm{MCH}$ values of Omanis, $\mathrm{GM}=24.8$ (SD 6.5) $\mathrm{pg}$, when compared to the western value 30.4 (SD 3.24) pg. That the cause of this hypochromia was largely the result of thalassaemia genes was indicated by the higher red cell counts of the Omani population $5 \cdot 2$ (SD $1.52) \times 10^{12} / 1$ compared to the non-Arab value of $4.7(\mathrm{SD} 1.2) \times 10^{12} / 1(\mathrm{p}=0.001)$, and the strong negative correlation between the $\mathrm{MCH}$ and the RBC ( $r=-0 \cdot 6)$. Moreover, the distribution of the $\mathrm{MCH}$ showed two significantly distinct populations (fig 2). The two groups were of nearly equal size. Group A consisted of approximately $50 \%$ of the subjects in whom the $\mathrm{MCH}$ ranged from 14 to $25 \mathrm{pg}(\mathrm{GM}=22 \cdot 8$ (SD $2.6 \mathrm{pg}$ )). Group B consisted of the other $50 \%$ of subjects with an $\mathrm{MCH}$ between 25 and $32 \mathrm{pg}$ (GM 27.3 (SD 4.3) pg). The difference between the geometric means of $\mathrm{A}$ and $\mathrm{B}$ was highly significant $(p=<0.001)$. The bimodal pattern of the $\mathrm{MCH}$ was constant to each subgroup of subjects when the whole population was subdivided into males or females, adults or children, and hospital patients or students. This is illustrated in fig 2 where only the male subgroup populations are shown as an example. It is assumed that the cause of the severe hypochromia in group $A$ is $\beta$ or $\alpha$ thalassaemia genes or iron deficiency. The cause of the hypochromia of the less severe group B is $\alpha$ thalassaemia or iron deficiency.

\section{HIGH Hв $A_{2} \beta$ THALASSAEMIA}

The levels of $\mathrm{Hb} \mathrm{A}_{2}$ were measured on 400 blood samples from the total population of 952 who had an $\mathrm{MCH}$ of less than $24 \mathrm{pg}$ (group A). It was increased in 14 with values ranging from 4.5 to $5 \cdot 6 \%$. This gives an overall frequency of high $\mathrm{Hb} \mathrm{A}_{2} \beta$ thalassaemia genes in the total population of 0.015 .

\section{$\alpha$ THALASSAEMIA}

Because there is no simple diagnostic marker for $\alpha$ thalassaemia, and it is impractical to carry out DNA analysis on 1000 people, it was decided to select eight samples at random from patients whose haematological indices indicated $\alpha$ thalassaemia trait; namely an $\mathrm{MCH}$ of $<25 \mathrm{pg}$, a normal $\mathrm{Hb} \mathrm{A}_{2}$, and a normal ferritin. These were then sent blind to another laboratory for $\alpha$ gene analysis. The results showed that all eight patients were homozygous for the $\alpha^{+}$deletional $(-\alpha /)$ thalassaemia gene (table 2$)$. 
Table 2 A comparison between the haematological parameters and the $\alpha$ gene status of 11 patients after Southern blotting analysis.

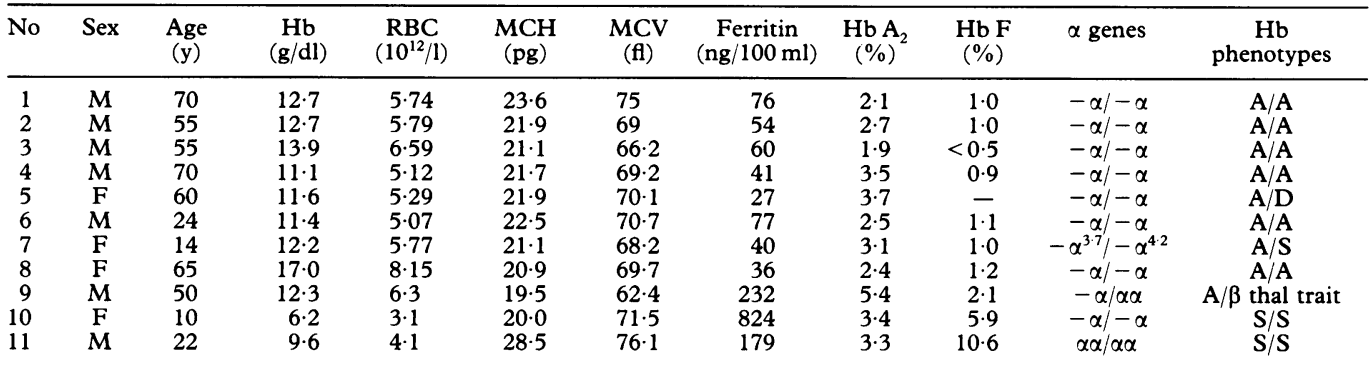

Samples 1 to 8 were diagnosed as having $\alpha$ thalassaemia based on the $\mathrm{MCH}, \mathrm{Hb} \mathrm{A}_{2}$, and ferritin level. Sample 9 was a known case of

$\beta$ thalassaemia trait. shown since their genotypes are important in the light of the data shown in table 4 .

Once confirmed, the frequency of the gene in Omanis could now be estimated with some degree of certainty by only measuring the $\mathrm{MCH}, \mathrm{Hb} \mathrm{A}_{2}$, and ferritin levels. For this we examined 127 of the male student population.

The $\mathrm{MCH}$ distribution pattern of this group is shown in fig 2 . There were 63 students with a severe hypochromia with an $\mathrm{MCH}$ of 20 to $25 \mathrm{pg}$. Of these, 58 had normal ferritins of greater than $25 \mathrm{ng} / \mathrm{ml}$ and only one had a raised $\mathrm{Hb} \mathrm{A}_{2}$. It was therefore assumed that the only cause of the hypochromia of the remaining 57 was homozygosity for $\alpha^{+}$thalassaemia $(-\alpha)$ $-\alpha$ ) which gives a frequency among the male students of $57 / 127=0 \cdot 448$. Since the relative size and $\mathrm{MCH}$ distribution of this student group ran true throughout the whole population it seems realistic to assume that the frequency of this type of $\alpha$ thalassaemia is also true for the whole population.

To test this further the frequency was calculated from the number of cord bloods which contained 3 to $5 \% \mathrm{Hb}$ Bart's $\left(\gamma_{4}\right)$ and also from the levels of $\mathrm{Hb} \mathrm{S}$ in $\mathrm{A} / \mathrm{S}$ carriers.

Of the 247 cord bloods analysed, $104(42 \%)$

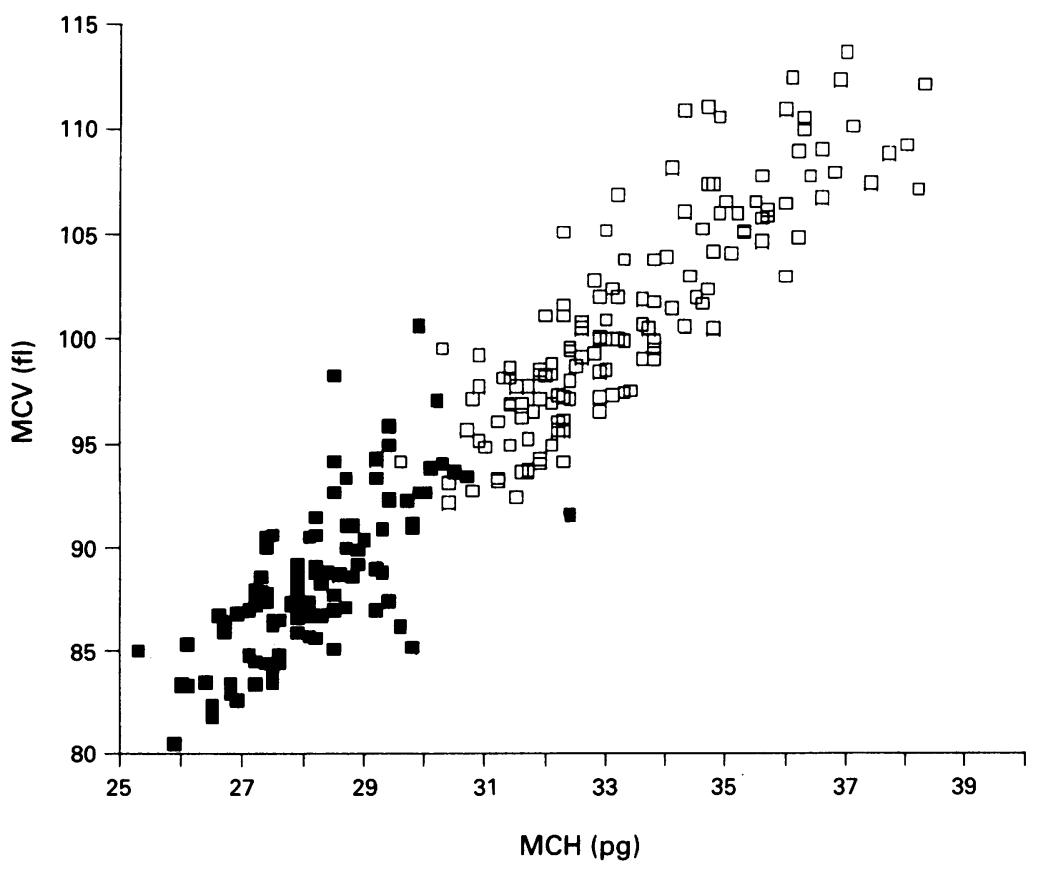

Figure 3 Correlation between the MCV and MCH of 247 cord blood samples of Omani neonates $(r=0.926) ; 104$ of the samples (42\%) contained 3 to $5 \%$ Hb Bart's and are signified by dark squares. These were virtually always associated with an $M C V$ of less than $100 \mathrm{fl}$ and an $\mathrm{MCH}$ of less than $31 \mathrm{pg}$. contained visible ( 3 to $5 \%$ ) Hb Bart's (fig 3). This is well recognised to be associated with a two deletional type of $\alpha$ thalassaemia. ${ }^{8}$ This value gives a frequency of two deletional $\alpha$ thalassaemia in the population of $0 \cdot 42$. Finally, among the 93 sickle cell trait patients, 38 had levels of $\mathrm{Hb} S$ less than $30 \%$ (fig 4 ). Again such levels are thought to be the result of association with two $\alpha$ gene deletional $\alpha$ thalassaemia and this value would give a frequency of 0.41 .

The major cause of the hypochromia in group B is also probably the result of a milder form of $\alpha$ thalassaemia most likely $-\alpha / \alpha \alpha$ since only three of the 64 students in group $B$ had low ferritin levels and all had normal $\mathrm{Hb} \mathrm{A}_{2}$ levels. From the frequency of the homozygosity of the $-\alpha$ haplotype of $45 \%$ one can compute that the frequency of the $-\alpha / \alpha \alpha$ genotype is 0.44 and $\alpha \alpha / \alpha \alpha$ is 0.11 in this population. It is worth stressing that the frequency of the $-\alpha$ haplotype is remarkably high at 0.67 .

SICKLE HB

Of the 952 samples tested, 58 gave a positive sickling test $(6 \cdot 1 \%)$ and all were shown to be heterozygotes for $\mathrm{Hb} \mathrm{A}$ and $\mathrm{Hb} \mathrm{S}$. This gives an $\mathrm{Hb} \mathrm{S}$ frequency of 0.061 . Of the 247 cord bloods analysed by acid electrophoresis, 15 were found to contain sickle haemoglobin $(\mathrm{Hb}$ $\mathrm{F}, \mathrm{A}$, and S) which would give a frequency of $0 \cdot 060$. If correct, there should be $3 \cdot 7$ homozygotes per 1000 live births and approximately 5000 to 6000 in the country.

Of interest is the distribution of $\mathrm{Hb} \mathrm{S}$ in heterozygotes which is shown in fig 4 , where the percentage of $\mathrm{HbS}$ ( $\mathrm{x}$ axis) is correlated with the patients' $\mathrm{MCH}$ (y axis). Two distinct but equal populations are seen. None of these carriers was iron deficient. Therefore the strong correlation with the $\mathrm{MCH}(\mathrm{r}=0.98)$ would indicate that the amount of $\mathrm{Hb} S$ found is mainly a function of red cell hypochromia and in the Omani population is largely dictated by the number of functional $\alpha$ chain genes.

GD

Among the 435 males examined, 119 (27.3\%) were found to be G6PD deficient on screening and in all these the activity of the enzyme was less than $10 \mathrm{mU} / 10^{9} \mathrm{RBCs}$. Of the 517 females tested, 64 were deficient; 57 of these $(11.0 \%)$ had values of less than $10 \mathrm{mU} / 10^{\circ} \mathrm{RBCs}$ and 


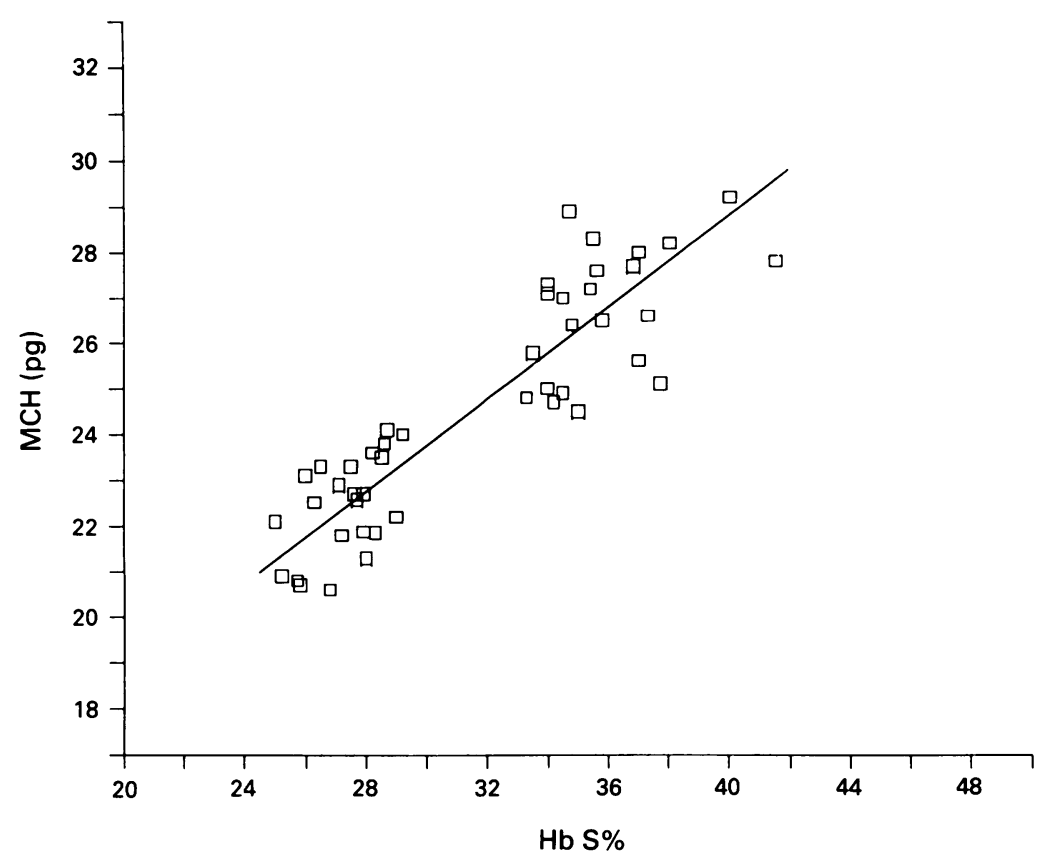

Figure 4 Correlation between the $\mathrm{MCH}$ and the level of $\mathrm{Hb} \mathrm{S}$ in sickle trait carriers $(r=0.98)$. The ferritin levels were normal in all samples indicating that the level of $\mathrm{Hb} S$ is purely a function of active $\alpha$ genes. Two distinct populations of $S$ ( $x$ axis) are clearly seen.
Table 3 Frequencies of erythrocyte genetic defects in Omanis.

\begin{tabular}{lll}
\hline Gd- & Males & $0 \cdot 27$ \\
& Females & $0 \cdot 11$ \\
Hb S & & $0 \cdot 061$ \\
$\beta$ thal & & 0.015 \\
$\alpha$ thal & $-\alpha / \alpha \alpha$ & 0.48 \\
& $-\alpha /-\alpha$ & 0.45 \\
\hline
\end{tabular}

supported by DNA analysis of the $\beta$ globin genes of 29 patients, 19 of whom $(70 \%)$ showed the common Indian allele IVS1-5 G $\rightarrow C$. This means that the true frequency for the Omani Arab is much lower and of the order of 0.0038 .

\section{$\alpha$ THALASSAEMIA}

We conclude from the data derived from examining the male student population that the $\alpha$ thalassaemia gene is endemic among the Omani and that it is the result of the presence of the $\alpha^{+}(-\alpha /)$ gene. This is not only based on the DNA analysis but is supported by the fact that non-mutational $\mathrm{Hb} \mathrm{H}$ disease $(--/-\alpha)$ and Bart's hydrops fetalis (- $-/--)$ have to our knowledge never been reported in Peninsular Arabs. From the red cell parameters 45\% of the population are homozygous for this gene $(-\alpha /-\alpha)$. This is supported by the frequency of $\mathrm{Hb}$ Bart's in cord bloods and the levels of $\mathrm{Hb} \mathrm{S}$ in carriers.

Furthermore, it is likely that the major cause of the hypochromia among the other half of the population, with $\mathrm{MCH}$ values between 25 to $28 \mathrm{pg}$, is heterozygosity for the $\alpha^{+}$gene $(-\alpha /$ $\alpha \alpha$ ). If correct, it means that the $-\alpha /$ haplotype is pandemic. The very high frequency is probably because of Oman's geographical isolation. However, it also implies that this genetic defect is harmless and, moreover, it probably affords some biological advantage. There is no evidence that a single $\alpha$ gene deletion affords protection against malaria. Of clinical importance is that $\alpha / \beta$ thalassaemia must be common among our 117 homozygous $\beta$ thalassaemia patients who are already in a hypertransfusion programme. So far five out of 10 of our patients have now been shown by DNA analysis to be heterozygous for $\alpha^{+}$ and homozygous for $\beta^{+}$thalassaemia genes $\left(-\alpha /-\alpha \alpha \beta^{+} / \beta^{+}\right)$and may well have shown a thalassaemia intermedia-like picture. Therefore, where $\alpha$ thalassaemia is endemic complete $\alpha$ and $\beta$ globin gene analysis is essential when these patients first present before a long term hypertransfusion policy is adopted. We have found that to discontinue transfusion after years is clinically difficult because of cardiac siderosis and decompensation, and psychologically disturbing for the patients and parents.

HIGH Hв $A_{2} \beta$ THALASSAEMIA GENE

The frequency of 0.015 is relatively low but in keeping with the frequencies found in Saudis, Yemenis, and UAE nationals." Using this frequency it was calculated that there would be 300 homozygotes among Oman's population of 1.5 million and indeed 137 patients are registered at this hospital. However, after examining the tribal names of homozygote patients, $75 \%$ were found to be non-Arab and had originated from Beluchistan two centuries ago. This was

\section{GLUCOSE 6 PHOSPHATE DEHYDROGENASE} DEFICIENCY

The frequency of $\mathrm{Gd}^{-}$in males $(0 \cdot 27)$ and in females $(0 \cdot 11)$ is the second highest reported. ${ }^{9}$ From these frequencies it is calculated that there are nearly 400000 people who are deficient in this country. However, as stated previously, clinically there are relatively few oxidative haemolytic crises. ${ }^{1}$ 
Varieties of fava bean are grown and commonly eaten but very few patients suffer haemolysis. However, there are two other quantitatively more reliable stress factors, namely the use of antimalarials and oxidative antibiotics. In Oman in 1990/91 there were 27000 cases reported of falciparum malaria which it is presumed were treated. Moreover, during 1991/92, 78 cases of falciparum malaria were admitted to this hospital and all received full doses of chloroquine therapy. Of these patients, 36 were G6PD deficient and none of them suffered from haemolysis. Similarly according to the country's main drug distributor, 34000 patient doses of Septrin ${ }^{\mathrm{R}}$ were issued in 1990/91. From our frequencies of the 'at risk population', approximately one fifth of the patients who received antimalarials or Sep$\operatorname{trin}^{\mathrm{R}}$ would have been G6PD deficient, that is, 12200 patients. In spite of this, the University Hospital has only admitted five cases of oxidative haemolysis during 1990 to 1992 from a catchment area of one quarter of the country's population and in three of these patients there were exceptional circumstances. One had severe chronic renal failure and had been given Septrin ${ }^{R}$ and chloroquine. Another was given simultaneously chloroquine, primaquine, and Septrin ${ }^{R}$. The third was a case of leprosy given high dose Dapsone ${ }^{\mathrm{R}}$. The other two patients were mango growers living in the same area and had been harvesting the fruit a few days before admission, but the cause of their haemolysis remains obscure. However, it is clear that oxidative haemolysis is rare. This has been recently reviewed and stressed by Beutler. ${ }^{10}$

\section{SICKLE CELL ANAEMIA}

Finally the very high frequency of $\alpha$ thalassaemia has been found to modify the clinical and haematological picture markedly in patients homozygous for the sickle gene. At present 177 patients homozygous for $\beta^{\text {s }}$ are registered at the hospital. The haematological data are summarised in table 4 . Twelve percent $(12 \%)$ have a normal $\mathrm{MCH}$ and presumably a normal complement of $\alpha$ genes, $28 \%$ had $\mathrm{MCH}$ values of 27 to $25 \mathrm{pg}$ and are probably $-\alpha / \alpha \alpha$, and $60 \%$ had an $\mathrm{MCH}$ of 25 to $20 \mathrm{pg}$ and are probably $-\alpha /-\alpha$.

Among this group the most obvious anomaly is that the $1: 1$ ratio of $-\alpha / \alpha \alpha:-\alpha /-\alpha$ seen in the overall population (and the $\mathrm{HbA} / \mathrm{S}$

Table 4 The mean of some haematological values of $177 \mathrm{Hb}$ S/S patients.

\begin{tabular}{lrcccccccc}
\hline $\begin{array}{l}\text { Probable } \\
\text { genotype }\end{array}$ & No & $\begin{array}{c}\text { Age } \\
(\mathrm{y})\end{array}$ & $\begin{array}{c}\mathrm{Hb} \\
(\mathrm{g} / \mathrm{dl})\end{array}$ & $\begin{array}{c}\mathrm{MCH} \\
(\mathrm{pg})\end{array}$ & $\begin{array}{c}\mathrm{RBC} \\
\left(10^{12} / \mathrm{l}\right)\end{array}$ & $\begin{array}{c}\mathrm{MCV} \\
(\mathrm{fl})\end{array}$ & $\begin{array}{c}\text { Retic } \\
(\%)\end{array}$ & $\begin{array}{c}\mathrm{Hb} \mathrm{A_{2 }} \\
(\%)\end{array}$ & $\begin{array}{c}\mathrm{Hb} \mathrm{F} \\
(\%)\end{array}$ \\
\hline$\alpha \alpha / \alpha \alpha$ & 24 & 13.1 & 8.1 & 29.7 & 2.64 & 88.6 & 19.2 & 2.99 & 9.4 \\
$-\alpha / \alpha \alpha$ & 50 & 9.9 & 8.2 & 26.5 & 3.14 & 81.7 & 13.9 & 2.97 & 12.0 \\
$-\alpha /-\alpha$ & 103 & 11.0 & 8.7 & 21.8 & 3.99 & 68.8 & 10.5 & $3.39 *$ & 12.2
\end{tabular}

A comparison of the means of some haematological parameters among 177 patients homozygous for the $\beta^{s}$ gene. This was confirmed by screening of parents. The three groups have been for the $\beta^{s}$ gene. This was confirmed according to the MCH: $M C H>28 \mathrm{pg}, 27-25 \mathrm{pg}$, and $<25 \mathrm{pg}$. The $\alpha$ gene complement shown is speculative. See text for discussion.

The significant differences seen are the decreases in the ratio of $-\alpha / \alpha \alpha,-\alpha /-\alpha$ from $1: 1$ in the normal Omani population to $0 \cdot 5: 1$. Also, as assessed by the reticulocyte count the rate of haemolysis would appear to become less as the $\mathrm{MCH}$ falls but the numbers are too few at presen to provide reliable statistical data.

* The higher $\mathrm{Hb} \mathrm{A}_{2}$ value is probably because when $\alpha$ chains are rate limiting the $\alpha: \delta$ affinity is greater than $\alpha: \beta^{\mathrm{s}}$ (to be published). population) has now fallen to $0 \cdot 5: 1$ (table 4 ). There is no clear reason for this. The Hb levels and $\mathrm{Hb} F$ levels are the same in both groups. The only difference is that the mean age of the $-\alpha / \alpha \alpha$ group is somewhat lower, but this is not significant. One could postulate either early death of the $-\alpha / \alpha \alpha$ patients or that this genotype is much more benign than $\alpha \alpha / \alpha \alpha$ or $-\alpha /-\alpha$ and that they do not attend hospital and therefore remain undiagnosed. However, it may be because the determination of the $\mathrm{MCH}$ of the red cells in sickle cell disease using automated machines is unreliable owing to poor lysis of sickled cells. The answer will only come when the $\alpha$ gene status of each patient is determined.

The clinical picture that is emerging in the 103 patients with an $\mathrm{MCH}$ of $<25 \mathrm{pg}\left(?-\alpha /-\alpha / \beta^{\mathrm{s}} /\right.$ $\beta^{s}$ ) is that they have an increased frequency of painful bone crises especially lower vertebral (average $6 \cdot 3 /$ patient/year) than the non $-\alpha$ thalassaemia $\beta^{\text {s }}$ homozygotes $(2 \cdot 1 /$ patient/year). Moreover, persistent splenomegaly is usual into adolescence, by which time all are hypersplenic, with low white cell and platelet counts. Twentysix of our patients have had to be splenectomised since they required regular transfusion to maintain their haemoglobin level above $6 \mathrm{~g} / \mathrm{dl}$. The lack of splenic infarction may be because of a combination of the lower MCV of the sickle cells and the differences in the anatomy of splenic microcirculation as compared with that of the bones. However, the gross splenomegaly found in a proportion of our patients might be the result of chronic malaria.

Finally it must be stressed that of these 103 patients only five are aged over 20 years and only one over 30 . Early death therefore would appear to be common. Although this may be the result of environmental factors rather than a cellular event, it is clear that loss of two $\alpha$ genes does not ameliorate the sickle cell disease.

We would like to thank Professor Lucio Luzzatto for his helpful comments and Mr David Gravell for providing some of the data.

1 White JM, Byrne M, Richards R, Buchanan T, Katsoulis E, Weerasingh K. Red cell genetic abnormalities in Peninsular Arabs: sickle haemoglobin, G6PD deficiency, and $\alpha$ and $\beta$ thalassaemia. $\mathcal{F}$ Med Genet 1986;23:245-51.

2 Old JM, Higgs DR. Gene analysis. In: Weatherall DJ, ed. The thalassaemias. Methods in haematology. Edinburgh: Churchill Livingstone, 1983;6:74.

3 Feinberg AP, Vogelstein B. A technique for radiolabelling DNA restriction endonuclease fragments to high specific activity. Anal Biochem 1983;132:6.

4 Church GM, Gilbert W. Genomic sequencing. Proc Natl Acad Sci USA 1984;81:1991.

5 Lauer J, Shen CKJ, Maniatis T. The chromosomal arrangement of human $\alpha$-like globin genes: sequence homology and $\alpha$-globin gene deletions. Cell 1980;20:119.

6 Proudfoot NJ, Gil A, Maniatis T. The structure of the human zeta-globin gene and a closely linked, nearly identical pseudogene. Cell 1982;31:553.

7 Varawalla NY, Old JM, Sarkar R, Venkatesan R, Weatherall DJ. The spectrum of $\beta$-thalassaemia mutations on the all DJ. The spectrum of $\beta$-thalassaemia mutations on the
Indian subcontinent: the basis for prenatal diagnosis. $B r f$ Haematol 1991;78:242-7.

Haematol 1991;78:242-7.
8 Wasi P, Na-Nakorn S, Pootrakul SN. The $\alpha$ thalassaemias. Clin Haematol 1974;3:383-410.

9 Kurdi-Haider B, Mason PJ, Berrebi A, et al. Origin and spread of the glucose-6-phosphate dehydrogenase variant G6PD-Mediterranean) in the Middle East. Am $\mathcal{f} \mathrm{Hum}$ Genet 1990;47:1013-19.

10 Beutler E. Glucose 6 phosphate dehydrogenase deficiency. N Engl f Med 1991;324:169-74. 